\title{
LIABILITY FOR THE TORTS OF INDEPENDENT CONTRACTORS IN CALIFORNIA
}

The extensive growth of exceptions to the rule that an employer is not liable for the torts of his independent contractor ${ }^{1}$ has given rise to serious questioning of this rule by courts and legal writers over the past half century. ${ }^{2}$ At least one American court has phrased the precarious status of the rule as being "little more than an introduction to the catalogue of exceptions." 3 That these exceptions, whose purpose is to impute to the employer liability for his contractor's negligence, are well-established is beyond question. ${ }^{4}$ Only the naive would assert today, as the California Supreme Court did in 1857, that "the relation between the parties was that of independent contractors .... To this relation the doctrine of respondeat superior does not apply ...." Clearly it is precisely this doctrine, respondeat superior, which does cause liability to be imposed on the employer when lie is limself entirely free of fault. ${ }^{6}$ The negligence of the contractor, like the negligence of the employee or of the agent, may be in inany cases imputed to the employer.

The subject of the independent contractor in our legal system covers an immense area. Of necessity this discussion must be circumscribed with certain limitations so that the problem of the extent to which the numerous exceptions to the

1 "An independent contractor is one who, in rendering services, exercises an independent employment or occupation, and represents his employer only as to the results of his work, and not as to the means whereby it is to be accomplished .... The chief consideration which determines one to be an independent contractor is the fact that the employer has no right of control as to the mode of doing the work contracted for." Green v. Soule, 145 Cal. 96, 99, 78 Pac. 337, 339 (1904).

2 See Snyder v. Southern Cal. Edison Co., 44 Cal. 2d 793, 285 P.2d 912 (1955); Lamb v. South Unit of Jehovah's Witnesses, 232 Minn. 259, 45 N.W.2d 403 (1950) ; Lipman v. WellMix Concrete, Inc., 138 N.Y.S.2d 316 (1954); Prosser, Torts 357 (2d ed. 1955); Harper, TORTS $\$ 292$ (1933); MecheM, OUTLINES OF AgENCx $\$ 484$ (4th ed. 1952); REsTateMant, TORIs \$\$ 410-429 (1934); Chapman, Liability for the Negligence of Independent Contractors, 50 L.Q. REv. 71 (1934); Douglas, Vicarious Liability and Administration of Risk, 38 Yare L.J. 584, 720 (1929); Fleming, Vicarious Liability, 28 TUL. L. Rev. 161 (1954); Friedman, Incidence of Liability in Nuisance, 59 L.Q. REv. 63 (1943) ; Morris, The Torts of an Independent Contractor, 29 IrL. L. Rev. 339 (1935); Smith, Collateral Negligence, 25 MINN. L. REv. 399 (1941) ; Steffen, Independent Contractor and the Good Life, 2 U. CHI. L. Rev. 501 (1935).

3 Pacific Fire Ins. Co. v. Kenny Boiler and Mfg. Co., 201 Minn. 500, 503, 277 N.W. 226, 228 (1937).

4 The rule of employer nonliability has been substantially eliminated by the English courts. 50 L.Q. REv. 71 (1934). In 1933 Professor Harper predicted that the growing list of exceptions would soon envelope the rule. HARPER, TORTs $\$ 292$ (1933). But cf. Prosser, TorTs 361 (2d ed. 1955): "Notwithstanding wishful thinking on the part of many legal writers, however, the courts have as yet been unwilling to extend the principle [of nondelegation] to every case where reasonable care is required of the contractor." See also Brown, Liability for the Torts of Independent Contractors in West Virginia, 55 W. VA. L. Rev. 216 (1953). "The general rule of nonliability of an employer for the acts of an independent contractor is subject to numerous exceptions." Snyder v. Southern Cal. Edison Co., 44 Cal. 2d 793, 797, 285 P.2d 912, 914 (1955).

5 Boswell v. Laird, 8 Cal. 469,490 (1857).

6 "But it seems that it [the rule of nonliability] could be considered as an exception to the agency rule because if it were swallowed by exceptions the agency rule would spring up and take its place simce the doctrine of respondeat superior, meaning literally, 'let the principal answer,' appears to be the most logical theory upon which the liability of the employer for the acts of the independent contractor can be predicated." Brown, Liability for the Torts of Inde. pendent Contractors in West Virginia, 55 W. VA. L. Rev. 216, 219 (1953). See also Douglas, Vicarious Liability and Administration of Risk, 38 YaLE L.J. 584, 720 (1929); Morris, The Torts of an Independent Contractor, 29 IrL. L. Rev. 339 (1935); Steffen, Independent Contrator and the Good Life, 2 U. Crr. L. REv. 501 (1935). 
rule of nonliability have been adopted, rejected, or passed over in California may be pinpointed. Thus this Comment will omit any discussion of who is an independent contractor ${ }^{7}$ or of the effect of the employer's own negligence in hiring an incompetent contractor ${ }^{8}$ or of the parallel limiting doctrine of collateral negligence. ${ }^{9}$ The inquiry will be concerned with situations in which the employer is entirely free from personal fault, ${ }^{10}$ in that the injury arose solely from the negligence of the independent contractor, but yet the employer is held liable.

\section{Reasons for the Rule and Its Exceptions}

The commonly stated justification for refusing to apply the doctrine of respondeat superior to the relationship of employer and independent contractor is the employer's complete lack of control over the actions of the contractor. ${ }^{11}$ The contractor is controlled only in so far as the end result is concerned, but is in no way subject to the employer's control as to the manner of accomplislimg this result.

The development of exceptions is based, in theory at least, on the principle that "the enterprise is still the employer's, since he remains the person primarily to be benefited by it, that he selects the contractor, and is free to insist upon one who is financially responsible, and to demand indemnity from him; and that the insurance necessary to distribute the risk is properly a cost of his business."12 The presence of ultimate benefit to the employer coupled with a desire to reach into the "deep pocket" as a means of allocating risk to those most able to bear it has resulted in an ever broadening application of the doctrine of respondeat superior in the form of exceptions to the rule of nonliabihty. ${ }^{13}$

These exceptions encompass those duties which the law holds to be nondelegable, and those activities in which there is inherent or intrinsic danger in the very performance of the work. The former may arise by statute, contract, franchise or charter, or the common law. ${ }^{14}$ The latter, activities in which there is inherent or

7 See note 1 supra.

8 Where the employer hires an incompetent contractor to do the work contracted for, the employer is liable for the contractor's negligence on the theory that any injury is a direct result of the employer's own negligence. Risley v. Lenwell, 129 Cal. App. 2d 608, 277 P.2d 897 (1954); Skelton v. Fekete, 120 Cal. App. 2d 401, 261 P.2d 339 (1953).

o See Barrabee v. Crescenta Mntual Water Co., 88 Cal. App. 2d 192, 198 P.2d 558 (1948), substantially overruled in Snyder v. Southern Cal. Edison Co., 44 Cal. 2d 793, 285 P.2d 912 (1955) ; Prosser, Torts 361 (2d ed. 1955) ; Smith, Collateral Negligence, 25 MINN. L. Rev. 399 (1941).

10 For a discussion of the relationship between fault and liability in the modern industrial community see EHRENZWeig, Negligence Without Fault (1951).

11 Snyder v. Southern Cal. Edison Co., 44 Cal. 2d 793, 285 P.2d 912 (1955), citing with approval Harper, Torts \& 292 (1933); Knell v. Morris, 39 Cal. 2d 450, 247 P.2d 352 (1952); Eli v. Murphy, 39 Cal. 2d 598, 248 P.2d 756 (1952); Prosser, Torss 357 (2d ed. 1955) and authorities cited therein.

12 Prosser, Torts 357 (2d ed. 1955).

13 MeChede, OUtLINES OF AgENCY \& 469 (4th ed. 1952); Douglas, Vicarious Liability and Administration of Risk, 38 Yate L.J. 584, 720 (1929).

14 Snyder v. Southern Cal. Edison Co., 44 Cal. 2d 793, 285 P.2d 912 (1955) (statutory duties of public utility); Eli v. Murphy, 39 Cal. 2d 598, 248 P.2d 756 (1952) (common carrier franchise); Colegrove v. Smith, 102 Cal. 220, 36 Pac. 411 (1894) (municipal licenses; contractual duty); Williams v. Fresno C. \& I. Co., 96 Cal. 14, 30 Pac. 961 (1892) (contract called for trespass to plaintiff's property). But cf. Gilbert v. Rogers, 117 Cal. App. 2d 712, 256 P.2d 574 (1953) (license by right does not create nondelegable duty).

An often litigated common law duty is that of lateral support. It is generally held that this duty cannot be delegated to an independent contractor. Law v. Phillips, $136 \mathrm{~W}$. Va. 761, 68 S.E.2d 452 (1952) ; Bower v. Peate, [1876] 1 Q.B. 321 (no delegation if injurious consequences 
intrinsic danger ${ }_{2}^{15}$ include a vast array and provide a fertile area for judicial widening of the exceptions. ${ }^{16}$

The fact that the two exceptions may be fundamentally the same seems never to have seriously troubled the courts. Frequently both rules are stated, or it is said that the duty is created by the inherent danger. ${ }^{17}$ In each case in which liability has been predicated on the inherent danger exception, one notes that there is also some special relationship between the employer and the injured party which can be characterized as something inore than sinply that the plaintiff was foreseeable. ${ }^{18}$ The California cases make this relationship highly important since there appears to be no case in which liability has been imposed on the basis of the inherent danger exception. ${ }^{19}$

\section{Exceptions to Employer Nonliability: Inherent or Intrinsic Danger}

In Boswell v. Laird, ${ }^{20}$ the earliest California case to state the rule of nonliability, the defendant landowner was adjudged not liable to a downstream owner

may result unless means are taken to prevent them); Fleming, Vicarious Liability, 28 TUn. $I$. REv. 161 (1954); Annot., 23 A.L.R. 984 (1923). Apparently this is now the rule in California. It was early held that where the contract called for the excavation of defendant's land "the defendant was . . . not liable if the damages [loss of lateral support of plaintiff's land] were produced by the act of an independent contractor, or lis servant." Aston v. Nolan, $63 \mathrm{Cal} .269$, 275 (1883). Subsequently the court commented: "Some would be disposed to question that decision [Aston v. Nolan] so far as it holds that the lot-owner could thus relieve himself fron the duty he owed to his coterminious owner. That point, however, is not involved leere." Green v. Berge, 105 Cal. 52, 58, 38 Pac. 539, 541 (1894) (no appeal was taken by defendant lotowner). This statement was lield to be an overruling of Aston $v$. Nolan. Wharam v. Investment Underwriters, 58 Cal. App. 2d 346, 351, 136 P.2d 363, 366 (1943). Compare Hedstrom v. Union Trust Co., 7 Cal. App. 278, 94 Pac. 386 (1908) with Williams v. Fresno C. \& I. Co., 96 Cal. 14, 30 Pac. 961 (1892).

15 See, Restateanent, Torts $\$ \$ 416,423$ (1934); Dinlion, Municipax Corporations $\$ 792$ (5th ed. 1911); Annots., 34 A.L.R.2d 493 (1954); 33 A.L.R.2d 89 (1954); 23 A.L.R. 1016, 1084 (1923) and authorities cited therein.

16 Prosser, TORTS 360 (2d ed. 1955) and cases cited therein.

17 Id. at 360 n.92; Annot., 23 A.L.R. 1081 (1923).

18 See, e.g., Fegeles Constr. Co. v. MacLaughlin Constr. Co., 205 F.2d 637 (9th Cir. 1953) (plaintiff was business invitee); Community Gas Co. v. Williams, 87 Ga. App. 68, 73 S.E.2d 119 (1952) (plaintiff was adjacent landowner); Stubblefield v. Federal Reserve Bank of St. Louis, 356 Mo. 1018, 204 S.W.2d 718 (1947) (plaintiff was passer-by on public street). Notwithstanding the special relationship between the employer and the injured party in the foregoing cases, liability rested squarely on the inherent danger exception.

${ }^{19}$ In Gaskill v. Calaveras Cement Co., 102 Cal. App. 2d 120, 226 P.2d 633 (1951), tho court recognized the existence of this exception, but held there was nothing "peculiarly dangerous unless carefully operated" about the operation of a motor vebicle (which in this case was a nrobile cement mixer!) $I d$. at 125,276 P.2d at 636 ; accord, Schmidlin v. Alta Planing Mill Co., 170 Cal. 589, 150 Pac. 983 (1915) (hauling paint bucket up the side of a building to paint a sign on the outside wall). In Barrabee v. Crescenta Mutual Water Co., 88 Cal. App. 2d 192, 198 P.2d 558 (1948) the court mentioned the inherent danger exception, but cited only Colegrove v. Smith, 102 Cal. 220, 36 Pac. 411 (1894). Colegrove was a license case involving street excavations by an abutting owner-the act causing injury was unlawful, a nuisance per se without a license and therefore the duty imposed by the license was nondelegable.

The courts have often used the term "inherent danger," but always in connection with a primary basis for liability. See and compare Snyder v. Southern Cal. Edison Co., 44 Cal. 2d 793, 285 P.2d 912 (1955) (duty imposed by statute involved considerable risk unless properly executed); Taylor v. Oakland Scavenger Co., 17 Cal. 2d 594, 110 P.2d 1044 (1941) (activity involving possible danger done under hicense of public authority); Risley v. Lenwell, $129 \mathrm{Cal}$. App. 2d 608, 277 P.2d 897 (1954) (hiring mcompetent contractor); Alonzo v. Hills, 95 Cal. App. 2d 778, 214 P.2d 50 (1950); (strict hability for blasting in populated area). In Boyd v. White, 128 Cal. App. 2d 641, 271 P.2d 92 (1954), the court rejected the view that the operation of aircraft was inherently dangerous.

208 Cal. 469 (1857). 
when a dam, negligently constructed by an independent contractor on defendant's land, broke and flooded plaintiff's property. ${ }^{21}$ The court held that since the activity was lawful and there was no defect in the original plan: ${ }^{22}$

For injuries occurring in the progress of the work before its completion and acceptance, the contractors alone were responsible to third parties .... In the present case, the damages are, in fact, claimed for the negligence and unskillfulness of the work of the contractors before its completion and acceptance, and it is sought to fasten a liability for such damages upon [defendant landowner] ... from the fact that it was in their mind that the undertaking originated, and it was their volition which set that undertaking into execution. If these reasons are sufficient to charge them, then upon the same principle, no enterprise requiring for its execution the skill, learning, and knowledge of professional men, could be undertaken, without risks on the part of the original projectors, which no prudent man would take.

One well inay wonder whether the activity was not one inherently dangerous unless special precautions were taken, so that in another day a court would be more disposed to find liability in the "deep pocket" of the landowner. However, even at this early date the court recognized an exception to the rule upon which the decision relied. The court noted that: ${ }^{23}$

If the injury complained of arose, not from the manner in which the embankment or dam was constructed, but from the fact that it was constructed at all; that is, if it was a structure ainounting to a nuisance, liability therefor would attach equally to [the landowner] ... and the contractors .... The authorities ... place the liability on the ground that every unan is bound to so use and manage his property as not to injure others.

While the rule of nonliability has been applied in later cases, its scope has been extensively limited. Similar statements of the rule appear in two subsequent cases involving ultra-hazardous activity. In Houghton v. Loma Prieta Lumber Co. ${ }^{24}$ the court lield only the contractor liable where blasting was conducted in an isolated inountain area. It was recognized that under certain circumstances blasting might prevent application of the rule of nonliability, but that when conducted in an isolated locale it is not so hazardous as to constitute a "nuisance per se."25 The rule was restated thirty years later in McGrath v. Basick Bros. Constr. Co. ${ }^{26}$ The $M c G r a t h$ case held, lowever, that blasting in a populated area was an ultrahazardous activity and the defendant landowner was held liable on the doctrine of strict hability. ${ }^{27}$ This case has been subsequently followed. ${ }^{28}$

Notwithstanding recognition of the doctrine of strict hability where the activity is of an ultra-hazardous nature, it is by no means certain that hability always

21 Note that the English case of Rylands v. Fletcher, [1868] L.R. 3 H.L. 330, was eleven years in the future. It is doubtful that the doctrine therein promulgated would have been accepted by the court in Boswell $v$. Laird, since there was, and is, nothing unusual about the storage of water by an upstream mountain property owner in Califorina.

22 Boswell v. Laird, 8 Cal. 469, 498 (1857). (Emphasis added.)

23 Id. at 494 .

24152 Cal. 500, 93 Pac. 82 (1907).

25 Id. at 506, 93 Pac. at 84.

267 Cal. App. 2d 573, 46 P.2d 981 (1935). The contractor was held to be liable on either of two grounds-negligence or ultra-hazardous activity.

27 The doctrine of strict liability imposes liability on the defendant regardless of the fault of either himself or another. On the other hand the inherent or intrinsic danger exception imputes liability to the fault-free employer from the admittedly negligent contractor. See Prosser, TORTS 317-18, 357-62 (2d ed. 1955).

28 Alonzo v. Hills, 95 Cal. App. 2d 778, 214 P.2d 50 (1950). 
will be imputed to the employer in these cases. In Luthringer v. Moore ${ }^{20}$ the contractor used hydrocyanic gas for the purpose of exterminating cockroaches from defendant employer's building. Plaintiff was injured upon entering the building subsequent to release of the gas. The contractor was held liable upon application of the ultra-hazardous activity doctrine; however, the building owner was exonerated by the jury under an instruction that defendant owner would not be liable unless he knew of the ineans by which the contractor intended to carry out his work..$^{30}$ No appeal was taken on this issue and the supreme court gave it no significant mention. Although it would seem that this is a typical situation for application of the inherent danger exception, whether the court in the future will be disposed to impute liability to the employer remains a matter for conjecture until the issue is directly raised.

The development of crop dusting by airplane presents an activity for which courts of other jurisdictions have imposed hability upon the employer on the ground that it is an activity inherently or intrinsically dangerous unless special precautions are taken. ${ }^{31}$ On the other hand the Cahfornia courts have imposed the same hability, ${ }^{32}$ with no attempt to utilize this exception, upon the doctrine of sic utere tuo ut alienum non laedas. ${ }^{33}$ Upon initial consideration of the prob$\mathrm{lem}^{34}$ reference was made by the court to the analagous situations of damage to property which results from drifting smoke, dust, noxious gases, or similar substances originating on a defendant's property. The court then stated: ${ }^{35}$

[H]e should not do the dusting, or have it done, under conditions which would indicate to a reasonably prudent person that damage to his neighbor would result. . . . No person is permitted by law to use his property in such a manner that damage to his neighbor is a foreseeable result.

Sic utere appears to be the primary bases for imputing liability to the employer. In addition, however, the nuisance exception, discussed below, ${ }^{36}$ seems to lave a place in the decision. The analogous situations referred to by the courts in the crop dusting cases are activities which have been considered to be nuisances for the maimtenance of which an employer las been held liable despite the intervention of an independent contractor. ${ }^{37}$

Regardless of which exception is felt to be the true basis of employer liability in the crop dusting cases, the reluctance of the courts to use the inherent danger exception is clear. Liability results because of the special relationslip between

2931 Cal. 2d 489, 190 P.2d 1 (1948) (a nonsuit was granted all defendants on the negligence count in the complaint). For a statement of the ultra-hazardous activity doctrine seo Restatement, ToRTs \$\$ 519-24 (1934).

30 Luthringer v. Moore, 31 Cal. 2d 489, 492, 190 P.2d 1, 3 (1948).

31 See, e.g., Crouse v. Wilbur-Ellis Co., 77 Ariz. 359, 272 P.2d 352 (1954); S. A. Gerrard Co. v. Fricher, 42 Ariz. 501, 27 P.2d 678 (1933); Chapman Chemical Co. v. Taylor, 215 Ark. 630, 222 S.W.2d 820 (1949); The Hammond Ranch Corporation v. Dodson, 199 Ark. 846, 136 S.W.2d 484 (1940) ; Pendergrass v. Lovelace, 57 N.M. 661, 262 P.2d 231 (1953) ; cf, Southwestern Bell Tel. Co. v. Smith, 220 Ark. 223, 247 S.W.2d 16 (1952); Alexander v. Seaboard Airlines R.R., 221 S.C. 477, 71 S.E.2d 299 (1952).

32 Parks v. Atwood Crop Dusters, Inc., 118 Cal. App. 2d 368, 257 P.2d 653 (1953); Miles v. A. Arena Co., 23 Cal. App. 2d 680, 73 P.2d 1260 (1937).

33 "Use your own property in such a manner as not to injure that of another." Brack, Law Dictionary (4th ed. 1951).

34 Miles v. A. Arena Co., 23 Cal. App. 2d 680, 73 P.2d 1260 (1937).

35 Id. at 683,23 P.2d at 1262 .

36 See text heginning at note 48 infrc.

37 Ibid. 
the parties-adjacent landowners-rather than the nature of the activity. In California it is the existence of a special relationship, and not inherent danger in the activity, which consistently appears as the basis for ignoring the general rule of employer nonliability.

Activities involving the use of electricity present still another example of the conspicuous absence of the inherent danger exception in this state. In Smith v. San Joaquin Light and Power Corp..$^{38}$ mjury from a power lime negligently left unprotected was sufficient to hold the employer liable despite delegation to an independent contractor of the work of removing the lines. The court did not refer to any duty of the defendant, saying merely that they beheved plaimtiff correct in his contention that an exception operated in this case. If the court was thinking in terms of the inherent danger exception, there is much authority for the proposition that activities involving electricity are within that category..$^{39}$ It would seem more reasonable that there was, in fact, a public franchise under which the defendant company was operating. The case has been cited as authority for the proposition that: ${ }^{40}$

Where an activity involving possible danger to the public is carried on under public franchise or authority the one engaging in the activity may not delegate to an independent contractor the duties or liabilities imposed on him by the public authority.

The inherent danger exception, so easily found where electricity is involved, has never been rehed upon by the courts.

It is obvious from the preceding discussion that the inherent danger exception has not been applied in California. However, in its most recent review of the problem, the California Supreme Court perhaps demonstrated an inchination to accept this exception in the future. In Snyder v. Southern Cal. Edison Co.41 the court quoted with approval Professor Harper's discussion of the inherent danger exception. ${ }^{42}$ It overruled suggestions in earlier cases that nondelegation by the employer is limited to maintenance or creation of nuisances. Further, it questioned the validity of Barrabee v. Crescenta Mutual Water Co.,43 a recent district court of appeal case, where it was held that the employer was insulated from liability because no danger inhered in the activity of digging wells on the employer's property. Despite the dearth of California authority on the inherent danger exception, its general acceptance in other jurisdictions ${ }^{44}$ would seem to make it incumbent upon plaintiffs' counsel to argne for its acceptance in this state. It may be, however, as will be subsequently indicated, that it is not the most desirable exception, and that its use is not necessarily required to achieve the desired result.

\section{Exceptions to Employers' Nonliability: Nondelegable Duties}

The term "nondelegable duty" is essentially the basic theory underlying the entire concept of the exceptions to the general rule of employer nonliability.

8859 Cal. App. 647, 211 Pac. 843 (1922).

39 Polk v. City of Los Angeles, 26 Cal. 2d 519, 159 P.2d 931 (1945) (no independent contractor involved). See Person v. Cauldwell-Wingate, 176 F.2d 237 (2d Cir. 1949); International Harvester Co. v. Sartain, 32 Tenn. App. 425, 222 S.W.2d 854 (1948); City of Austin v. Johnson, 195 S.W.2d 222 (Tex. Civ. App. 1946); Note, 9 So. Canr. L. Rev. 47 (1935).

40 Snyder v. Southern Cal. Edison Co., 44 Cal. 2d 793, 799, 285 P.2d 912, 916 (1955).

4144 Cal. 2d 793, 285 P.2d 912 (1955).

42 HARPER, TORTS $\$ 292$ (1933).

4388 Cal. App. 2d 192, 198 P.2d 558 (1948).

44 See Prosser, Torts 357-61 (2d ed. 1955); Harper, Torts $\$ 292$ (1933); Annots., 33 AI.R.2d 89 (1954); 12 A.L.R.2d 440 (1950); 23 A.L.R. 1016, 1084 (1923). But see Tedeschi v. Silver Rod-Patterson, 15 N.J. Super. 332, 83 A.2d 341 (App. Div. 1951). 
Whether the basis for refusing to allow delegation is the inherently dangerous character of the activity, or the much broader criterion of a statutory duty, or some special relationship between the employer and the injured party, liability is imposed because the duty of care which the employer had was one which could not be delegated. Be this as it may, the courts have long made a distinction between liability because of inherent danger and hability because there is said to exist a nondelegable duty. ${ }^{45}$ The rule of nondelegability is the broad and inclusive concept, while the supposedly separate doctrime of inherent danger is merely one of several bases for finding a justification for refusing to permit delegation. The latter justification is far less desirable from the point of view of predictability.48 Generally the attorney can advise that hability will remain with the employer because of a statute, franchise, or license which imposes a duty, or because of a special relationship between the employer and potential plaintiffs. However, one cannot always predict whether a particular activity will strike the trial judge or the reviewing court as one which reasonable men would say had the characteristic of inherent danger. As a basis for liability the special relationships between the employer and the injured party heremafter discussed provide a sound and stable foundation for applying exceptions to the general rule of nonliability-one which the courts of California, hike those of other jurisdictions, have seen fit to adopt with alacrity. ${ }^{47}$

\section{Nuisance}

There would seem to be hittle basis for criticisin of the application of the nondelegable duty exception to those cases wherein the doing of the activity contracted for involves the creation of a nuisance for which the employer himself would be hable, absent the intervention of an independent contractor. ${ }^{48}$ One cannot avoid hability for a forbidden act by contracting for its performance by another. ${ }^{40}$ As already indicated, the California courts early accepted this rule and have adliered to it consistently from its inception in Boswell v. Laird ${ }^{50}$ to the present. ${ }^{51}$

45 Prosser, TORTS 359 (2d ed. 1955) ; Harper, TORTS \$292 (1933); MECEEM, OUtIINES OF AGENCY $\$ 484$ (4th ed. 1952); RestateMENT, TorTs \$\$ 410-29 (1934).

46 "It should be noted that the predictability in this type of situation [inherent or intrinsic danger] is not high. In a considerable number of cases . . . recovery has been refused because of lack of sympathy for the doctrine, a holding that the work was not inherently dangerous enough to come within it, or a finding that the contractor's negligence was collateral." MECHEM, OUTIINES OF AGENCX 339 (4th ed. 1952). The last reason mentioned above is clearly in contradistinction to the "nondelegable" duty cases.

${ }^{47}$ See authorities cited at note 44 supra.

${ }^{48}$ See, e.g., MacLean v. San Francisco, 127 Cal. App. 2d 263, 273 P.2d 698 (1954); Brown Hotel Co. v. Sizemore, 303 Ky. 431, 197 S.W.2d 911 (1946).

40 "It is not the structure itself, but its character as a nuisance which causes the injury and creates the liability." Boswell v. Laird, 8 Cal. 469, 494 (1857) (recognizing nuisance as the sole exception to the general rule of employer nonliability).

50 See text at note 23 supra.

51 Snow v. Marian Realty Co., 212 Cal. 622, 299 Pac. 720 (1931), cited with approval in Snyder v. Southern Cal. Edison Co., 44 Cal. 2d 793, 285 P.2d 912 (1955) ; Luce v. Holloway, 156 Cal. 162, 103 Pac. 886 (1909); Spence v. Shultz, 103 Cal. 208, 37 Pac. 220 (1894); Barry v. Terkildsen, 72 Cal. 254, 13 Pac. 657 (1887) ; MacLean v. San Francisco, 127 Cal. App. 2d 263, 273 P.2d 698 (1954).

The limitation upon the nuisance exception, as upon the other exceptions, has been the doctrine of collateral negligence, i.e., liability has been limited to imjuries arising from a nuisance the creation of which is necessary to the performance of the work for which the contract was made. Green v. Soule, 145 Cal. 96, 78 Pac. 337 (1904); DuPratt v. Lick, 38 Cal, 691 (1869); see Smith, Collateral Negligence, 25 Manv. L. REv. 399 (1941). 
The statement in the Laird case that the nuisance must exist in the very nature of the completed performance ${ }^{52}$ has not hindered broader application of this exception. The finding that a nuisance exists is sufficient for the court to apply the doctrine of respondeat superior.

The nuisance exception is closely allied with two other exceptions. The first is that where a duty of care is imposed by statute or license the duty cannot be delegated and its violation is a nuisance per se..$^{53}$ The second is that where a possessor or owner of land has a duty to act with reasonable care for the protection of certain classes of persons, for example, invitees, passers-by, or adjacent landowners, the duty cannot be delegated. ${ }^{54}$

\section{Duty Imposed by Statute, License, or Franchise}

In Colegrove v. Smithis defendants had procured a municipal license to lay water pipes beneath the street. The license required the grantee to restore the streets to their former condition. An independent contractor, to whom the work of laying the pipes was let, negligently refilled the trench; the wheels of plaintiff's buggy became caught in the ditch, and as a result plaintiff was injured. In lolding the defendant employer liable the court said: ${ }^{56}$

Nor does the fact that they obtained from the city a franchise or permission to dig up the street ... relieve them from more than the unlawful character of the work. They stand in a contract relation to the public, represented by the city authorities, to do the work in the manner required by the ordinance, and cannot relieve themselves of the duty imposed by that contract by contracting with another to do the work. ... If done without authority, a nuisance would necessarily be created; and if not done in the manner required by the ordinance, the departure creates a nuisance.

It is clear from the quoted passage that in loolding the defendant liable the court used three separate doctrines, indicating the interrelation of one or more to the others. The license is first treated as a contract between the licensee and the public. It is well establisled that a contract duty cannot be delegated as regards the person to whom the duty is owed. ${ }^{57}$ Second, the court relies on the nuisance character of the act if done without a license- $a$ factor which lias already been

Note should be taken of the relationship between the nuisance exception and the sometimes used exception of direct consequences. For a discussion of the latter see Brown, Liability for the Torts of Independent Contractors in West Virginia, 55 W. VA. L. Rev, 216 (1953) and cases cited therein. Generally speaking this rule determines that an employer is liable for "injuries [which] . . . might have been anticipated as a direct or probable consequence of the performance of the work contracted for, if reasonable care is omitted in the course of its performance." Olio So. R.R. v. Morey, 47 Ohio St. 207, 24 N.E. 269 (1890), cited in Walton v. Cherokee Colliery Co., 70 W. Va. 48, 73 S.E. 63 (1911). It is the opinion of this writer that the direct consequences exception is merely the inverse of the collateral negligence exculpatory doctrine. The essential problem remains constant, for the court must still find either something in the character of the activity (inherent or intrinsic danger) or in the relationship of the parties which creates a nondelegable duty of care to the injured party.

52 See note 49 supra.

53 Snow v. Marian Realty Co., 212 Cal. 622, 624, 299 Pac. 720, 721 (1931) and cases cited therein.

54 Id. at 625,299 Pac. at 721.

55102 Cal. 220, 36 Pac. 411 (1894).

68 Id. at 224,36 Pac. at 411.

67 Water Co. v. Ware, 83 U.S. (16. Wall.) 566 (1872) ; Montgomery Ward and Co. v. Furlong, 219 F.2d 726 (10th Cir. 1955); Dekle v. Southern Bell Tel. \& Tel. Co., 208 Ga. 254, 66 S.E.2d 218 (1951); McCleary v. Sears Roebuck \& Co., 98 N.Y.S.2d 283 (N.Y. City. Ct. 1950). 
discussed. Last, the court adverts to the nature of a duty imposed by license, implying that such a duty is one which cannot be delegated. It is this last reasoning which pervades the subsequent cases and serves as the foundation for the rule of exception that when one is under a duty imposed by a license, statute, or franchise, that duty cannot be delegated to another for its performance. ${ }^{58}$

Nine years after Colegrove v. Smith, the court again touched upon the license exception. ${ }^{59}$ After reviewing the particular duties imposed by the license, the court concluded: 60

Other cautionary measures are enjoined on the contractor [the licensee] and the conclusion seems inevitable that [a] ... personal duty of an unassignable character was laid upon him.

\section{And again in Kirk v. Santa Barbara Ice Co.: ${ }^{61}$}

It [defendant] cannot evade responsibility upon the theory that the restoration of the sidewalk was under the control of an imdependent contractor, for its franchise imposes upon it a duty to the public which it cannot evade by the mere device of authorizing some person to have the work done. In such cases the rule respondeat sutperior appkes.

In neither of the two subsequent cases did the court advert to the contractual nature of the hicense upon which it seemed to rely to some degree in Colegrove v. Smith. This theory has substantially disappeared from the cases. Liability is found to exist wherever there is a duty imposed by statute or license, or where the act of the party would be unlawful without public authority - that is, a right acquired by public franchise. ${ }^{62}$

In the later cases there has developed another element which apparently must be found before vicarious liability will be imposed upon the employer: an element of possible risk or danger from the activity undertaken under authority of the license, statute, or franchise. ${ }^{63}$ Where the right to do the activity is given by public authority and the activity involves possible danger or the franchise imposes the duty of care because of the element of danger, the duty of care is nondelegable. ${ }^{64}$

The California courts have made, in one instance, a distinction between franchise rights granted as a matter of right and those granted only as a matter of grace. In Gaskill v. Calaveras Cement Co ${ }^{65}$ the Cahifornia District Court of Ap-

58 Restatement, Torts $\$ \S 417,428$ (1934). The leading English case is Grey v. Pullen, 5 Best \& S. 970, 122 Eng. Rep. 1091 (K.B. 1864) (highway excavation).

59 Luce v. Holloway, $156 \mathrm{Cal} .162,103$ Pac. 886 (1909).

60 Id. at 164, 103 Pac. at 887. (Emphasis added.)

61157 Cal. 591, 593, 108 Pac. 509, 510 (1910). (Emphasis added.)

62 Cf. Smith v. San Joaquin Light and Power Corp., 59 Cal. App. 647, 211 Pac. 843 (1922) (power line negligently left unprotected by independent contractor).

63 The Restatement of Torts states the following rule: "An individual or a corporation carrying on an activity which can be lawfully carried on only under a franchise granted by public authority and which involves an unreasonable risk of harm to others, is subject to liability for bodily harm caused to such others by the neghigence of a contractor employed to do work in carrying on the activity." Restatenent, Torts § 428 (1934) (emphasis added.); also see $i d$. $\S 417$ and cases cited at notes 78,79 , and 80 infra.

64 Snyder v. Southern Cal. Edison Co., 44 Cal. 2d 793, 285 P.2d 912 (1955) ; Eli v. Murphy, 39 Cal. 2d 598, 248 P.2d 756 (1952); Taylor v. Oakland Scavenger Co., 17 Cal. 2d 594, 110 P.2d 1044 (1941) ; Lehman v. Robertson Truck-A-Way, 122 Cal. App. 2d 82, 264 P.2d 653 (1953); cf. Williamson v. Southwestern Bell. Tel. Co., 265 S.W.2d 354 (Mo. 1954); Simon v. McCullough Transfer Co., 155 Ohio St. 104, 98 N.E.2d 19 (1951).

65102 Cal. App. 2d 120, 226 P.2d 633 (1951) (hearing denied by the supreme court March 29, 1951. Carter, J., voted for a hearing). 
peal for the Second District held that where a private contract carrier receives a license as a matter of right ${ }^{66}$ the franchise exception does not apply. This holding was subsequently approved by the supreme court in Eli v. Murphy, ${ }^{67}$ where the court distinguished the Gaskill case and held that since common highway carriers receive their franchise as a matter of grace, ${ }^{68}$ the duties imposed thereby are nondelegable. This distinction has been reluctantly followed by the California District Court of Appeal for Third District and approved by the supreme court at least to the extent of demial of a hearing. ${ }^{69}$

It would seem the better view that a license which imposes a duty of care upon the licensee should create a nondelegable duty, regardless of whether granted by grace or by right. It is the fact of making lawful an act which, if done without permission of public authority, would be unlawful-a nuisance per $\mathrm{se}^{70}$ - which slould determine the right to delegate. Certamly the cases supporting the traditional application of the franchise exception lend weight to this view. The activities for which permission is required bear distinctly public attributes; the public welfare is involved, or the public is served by the activity, or the activity has a limited number of participants upon whom the public is forced to rely. ${ }^{71}$

The element of danger said to be necessary for application of the franchise exception is that inherent in the nature of the activities for which pubhic permission is required. There would seem to be hittle basis for a distinction based on whether the right to carry on the activity is absolute or permissive. Thus the distinction now existing in the highway carrier cases ought not, and in all likelihood will not, be extended to other franchise exceptions to the rule of nonbiability. ${ }^{72}$

\section{Duty to Invitees and Other Duties of Owners or Possessors of Land}

The owner or possessor of land generally cannot delegate his duty to keep his premises in a reasonably safe condition. ${ }^{73}$ The cases falling within this exception

66 See CaL. Pub. UT. Code $\$ \$ 1061-73$.

6739 Cal. 2d 598, 248 P.2d 756 (1952).

68 See Cal. Pub. UT. Cone \$\$ 3571-72.

69 Gilbert v. Rogers, 117 Cal. App. 2d 712, 256 P.2d 574 (1953) (hearing was denied by the supreme court July 9, 1953. Carter, J., again voted for a hearing). The argument of Van Dyke, P.J., seems sound: "To us the distinction is not convincing. No one can engage in the transportation of freight over the pubhic highways except by license from the Public Utilities Commission. This grant of authority anyone must have if he wishes to carry on those activities. We think the factor of control by the Commission is important .... [T] hey may obtain their permits as a matter of right upon meeting the statutory conditions but they can retain them only by obeying the regulatious of the Commission. Nor does it seem to us that it can be said such carriers are engaged in a business open to all. It may be true, as stated by the Supreme Court, that the Legislature has exhibited special concern over higlwway common carriers and has classified them apart from other highway carriers, but certainly it has exhibited no lack of concern with respect to the safety of the operatious of the latter." Id. at 716, 256 P.2d at 576.

70 See note 62 supra.

71 See Prosser, TORTs 359 (2d ed. 1956), for extensive citations from other jurisdictions. To the same effect see MECHEM, OUTLINES OF AGENCY $\$ 484$ (4th ed. 1952).

72 See Snyder v. Southern Cal. Edison Co., 44 Cal. 2d 793, 285 P.2d 912 (1955).

73 The rule is well established in many American jurisdictions. Giem v. Williams, 215 Ark. 705, 222 S.W.2d 800 (1949) ; Frost v. Andies Candies Co., 329 Ill. App. 535, 69 N.E.2d 732 (1946) ; Kuhn v. Carlin, 196 Md. 318, 76 A.2d 345 (1950) ; Phegley v. Graham, 358 Mo. 551, 215 S.W.2d 499 (1948); Ahearn v. Roux, 96 N.H. 71, 69 A.2d 701 (1949); Levine v. Bochiaro, 137 N.J.L. 215, 59 A.2d 224 (1948); Janice v. State, 107 N.Y.S.2d 674 (Ct. Cl. 1951); Va. St. Fair v. Burton, 182 Va. 365, 28 S.W.2d 716 (1944); Myers v. Little Church by the Side of the Road, 37 Wash. 2d 897, 227 P.2d 165 (1951); Restatenent, ToRTs §§ 419-22 (1934). 
cover a broad area. Space limitations compel that they be treated together; the similarities are many and the differences basically slight. Broadly speaking, consideration will be given to the duty to invitees, the duty to maintain buildings in a reasonably safe condition, and the duty of abutting landowners to passers-by. The duties of adjacent landowners have already been considered. ${ }^{74}$

California has not always held that the possessor of land owes a nondelegable duty to invitees to keep his premises in a reasonably safe condition. ${ }^{75}$ Though the early influence of Boswell v. Laird long prevented the courts from utilizing the nondelegable duty exception, ${ }^{78}$ there has been a steady departure from this narrow approach, particularly in the cases dealing with the liability of owners or proprietors of places of public amusement. ${ }^{77}$ By 1943 the court referred to the exception as well settled law in this state, ${ }^{78}$ although citmg only district court cases ${ }^{79}$ and one of its own opinions ${ }^{80}$ along with several opinions from other jurisdictions ${ }^{81}$ and section 344 of the Restatement of Torts. ${ }^{82}$ Although there are few cases dealing with this precise point, it is safe to assume that the exception is not limited to places of public amusement: first, because the Restatement makes no such limitation and it is cited by the court with apparent full approval; second, and more significant, because the court has developed a different exception which is somewhat broader in scope and brings about precisely the same result. This latter exception is, of course, the nondelegable character of the duty of a possessor of land to build and maintain structures upon his land in a reasonably safe condition. Whether this exception and the invitee exception just noted are today distinguish. able is doubtful.

The leading California case expounding the maintenance exception is Brown v. George Pepperdine Foundation. ${ }^{83}$ In Pepperdine the defendant landlord contracted for repair of an elevator. The contractor was negligent and the plaintiff was injured. The court relied entirely on cases from other jurisdictions and section 422 of the Restatement of Torts 84 for authority that "a landlord cannot escape liability for failure to maintain elevators in a safe condition by delegating such

74 See text at notes $29-39$ supra.

75 Bennett v. Truebody, 66 Cal. 509, 6 Pac. 329 (1885).

76 Cf. Louthan v. Hewes, 138 Cal. 116, 70 Pac. 1065 (1902); Hedge v. Williams, 131 Cal. 455, 63 Pac. 721 (1901); Frassi v. McDonald, 122 Cal. 400, 55 Pac. 139 (1898); Brown v. Board of Trustees, 41 Cal. App. 100, 182 Pac. 316 (1919).

77 See, e.g., Johnstone v. Panama Pacific I.E. Co., 187 Cal. 323, 202 Pac. 34 (1921) (relying entirely on district courts of appeal cases and decisions from other jurisdictions).

78 McCordic v. Crawford, 23 Cal. 2d 1, 142 P.2d 7 (1943).

79 Basye v. Craft's Golden State Shows, 43 Cal. App. 2d 782, 111 P.2d 746 (1941); Szasz v. Joyland Co., 84 Cal. App. 259, 257 Pac. 871 (1927); Whyte v. Idora Park Co., 29 Cal. App. 342, 155 Pac. 1018 (1916).

80 Johnstone v. Panama Pacific I.E. Co., 187 Cal. 323, 202 Pac. 34 (1921).

81 Stickel v. Riverview Sharpshooters Park Co., 250 Ill. 452, 95 N.E. 445 (1911); Hollis v. Kansas City Retail Merchants' Ass'n, 205 Mo. 508, 103 S.W. 32 (1907) ; Engstrom v. Huntley, 345 Pa. 10, 26 A.2d 461 (1942); Wodnick v. Luna Park Amusement Co., 69 Wash. 638, 125 Pac. 941 (1912).

82 "A possessor of land who holds it open to the entry of the public for his busimess purposes is subject to liability to members of the public entering for such purposes for bodily harm caused to them by his failure to exercise a reasonably careful supervision of the appllances or methods of an independent contractor or concessionaire whom he has employed or permitted to carry on upon the land an activity which is directly on indirectly connected with his business use thereof." RESTATEMENT, TORTs $\$ 344$ (1934).

8323 Cal. 2d 256, 143 P.2d 929 (1943).

84 Comment $a$ of $\$ 422$ states in part: "The duty which a possessor of land owes to others to prat and maintain it in reasonably safe condition is nondelegable." (Empliasis added.) 
duty to an independent contractor." the supreme court, and relied on by the appellate courts in the years since it was handed down. ${ }^{86}$ There is no doubt that in California "the possessor of land is answerable for the negligent failure of an independent contractor to put or maintain buildings and structures thereon in reasonably safe condition." las been applied to hold the employer liable for injuries to a business invitee.88 Thus it is clear that the possessor of land has the same liability for negligent construction or maintenance of buildings upon his property whether he does the work himself or contracts with an imdependent contractor for its performance.

The Pepperdine case and those that have followed wipe out any vestige of immunity to invitees which the possessor of land had, excepting only liability for injuries caused by the collateral neghigence of the contractor. ${ }^{80}$ None of these cases rely to any extent on the character of the activity carried on. The key element necessary to prevent shifting hability from the employer to the independent contractor is the special relationship between the injured party and the employer. The relationship gives rise to the duty, and it is the character of the duty which makes it nondelegable. Certainly the element of risk has a role im determining when the duty is nondelegable. But when the nondelegability arises from the relationship between the parties rather than the character of the activity, the desirable element of predictability has a greater chance to operate. ${ }^{90}$ Witl the use of this exception, the California courts have placed the operation of the rule of nonliability upon a sound base for future development; at the same time the entire common law concept of msulation from liability has not been overturned. There remains a well articulated rule upon which the practitioner and the businessman can rely in calculating risks to be undertaken. ${ }^{91}$

There remains for consideration but one further exception involving an owner or possessors' liability - that of the abutting landowner who contracts for excavations to be made im an adjoining public way which endanger passers-by. ${ }^{92}$ Essentially this exception is merely another aspect of the combination of one or more of three exceptions already discussed, that is, activities lawful only with permission of public authority, nuisance, and the liability of a landowner to do nothing upon his land which endangers others.

The leading California case, Robbins v. Hercules Gasoline Co. ${ }^{93}$ a district court of appeal case, rehes on two license exception cases, Colegrove v. Smith ${ }^{94}$ and Luce v. Holloway, ${ }^{95}$ discussed earlier. This would seem to be the proper basis for disregarding the general rule of nonliability for two reasons: First, the activity would be a nuisance ${ }^{96}$ without the license simce it usually can be done only if the (1943)

85 Brown v. George Pepperdine Foundation, Inc., 23 Cal. 2d 256, 259, 143 P.2d 929, 930

80 Snyder v. Southern Cal. Edison Co., 44 Cal. 2d 793, 285 P.2d 912 (1955); Knell v. Morris, 39 Cal. 2d 450, 247 P.2d 352 (1952).

87 Knell v. Morris, 39 Cal. 2d 450, 456, 247 P.2d 352, 355 (1952).

88 Bazzoli v. Nance's Sanitarium, Inc., 109 Cal. App. 2d 232, 240 P.2d 672 (1952).

89 For a discussion of collateral negligence see note 51 supra.

90 See note 56 supra.

91 See Douglas, Vicarious Liability and Administration of Risk, 38 YAIE L.J. 584, 720 (1929).

02 See Restatenent, Torts $\$ 417$ (1934).

9380 Cal. App. 271, 251 Pac. 697 (1926).

$04102 \mathrm{Cal}$. 220, 36 Pac. 411 (1894).

95156 Cal. 162, 103 Pac. 886 (1909).

98 Sawaya v. DeCou, 60 Cal. App. 2d 146, 140 P.2d 98 (1943). 
license is procured; second, the before-mentioned doctrine of sic utere would seem to be applicable. Either of these reasons is sufficient and both are superior to use of the inherent danger exception which the courts of other jurisdictions lave applied to these situations. ${ }^{97}$ Both are based essentially on the nature of the duty, one arising by operation of the limitation on the riglit to do the activity, the other by the special relationship between the parties. The exception lias been well accepted by the supreme court and may be classed as one of the accepted exceptions in California. ${ }^{98}$

\section{Conclusion}

Notwithstanding early rejection of exceptions to the rule that the employer of an independent contractor is not liable for the contractor's negligence, the California courts liave kept pace with the developing trend away from the rule. There has been an apparent rejection of the exception based on the inherently or intrinsically dangerous character of the activity, and a well-defined effort to place liability of the employer upon a broader and more sound foundation. As a result, those who must advise and calculate risks liave been provided with a reasonable means of prognosticating whether employment of an independent contractor will result in a shifting of the risks of negligently performed activities.

Liability will be imposed where a nuisance results from conduct of the activity. It will arise where the activity is permitted only to those who apply and qualify under a license, a statute, or a franchise riglt. Finally, liability will be imposed where there is some special relationship existing between the parties, primarily where the employer is a possessor or owner of land and the activity on his premises causes injury to an invitee, a passer-by, or an adjacent landowner-that is, where the duty is said to be nondelegable. The rule of nonliability cannot be said to be nonexistent in California today, but it is clear that the rule stands suspect in the eyes of the courts. It is undoubtedly correct that in this state, as elsewhere, the rule serves primarily as an introduction to the exceptions.

\section{Marc H. Monkeimer}

97 See, e.g., Hanneken v. Eichler, 332 Ill. App. 437, 75 N.E.2d 244 (1947); Lamb v. South Unit of Jehovah's Witnesses, 232 Minn. 259, 45 N.W.2d 403 (1950); Lipman v. Well-Mix Cement, Inc., 138 N.Y.S.2d 316 (1954).

98 See, e.g., Snyder v. Southern Cal. Edison Co., 44 Cal. 2d 793, 285 P.2d 912 (1955); Knell v. Morris, 39 Cal. 2d 450, 247 P.2d 352 (1952); Katz v. Helbing, 215 Cal. 449, 10 P.2d 1001 (1932); Sawaya v. DeCou, 60 Cal. App. 2d 146, 140 P.2d 98 (1943). 